\title{
Frugal Powers: Detournement in the Age of Austerity
}

\section{Andrew Pendakis}

Every cluttered basement is a time machine. When a television that has sat discarded for a long while is suddenly taken up and experimentally (why not?) plugged in we experience a direct, yet fleeting connection to something like materially reversible time. Miraculously functional garbage: this is the form taken by redemption in an era of mass disposability. Against an expectation of inscrutable inner rot - one grounded, incidentally, not in any working knowledge of the circuits, but in the mere offensiveness to taste of a form's clunky anachronism - the machine modestly announces itself as capable of being counted among the things that are still here.

Is this not precisely the cultural fate of detournement, today, still working despite the odds against it, an old machine that still mysteriously works (and well)? In an aesthetic field characterized by structurally necessary extinction the signs of life left in detournement evoke something of this surprise taken in the presence of improbable survival. Why is it that the classical gesture of detournement should not have followed cubism or Bauhaus into the great (but dusty) toy-box of exhausted modernisms? Though every aesthetic genre or tactic that has ever been continues to exist - local art's world-system is a garish heaven in which every dead impressionism or illuminated manuscript can appear again forever, a pure, repetitive, asynchronous time - this mere existence is no sure mark of life, no mark of a form's capacity to induce, beget, or productively shame the present. Why is it, then, that what artist Keith Richardson semi-ironically calls "improved paintings" continues to exert a singular power over us, a visual force and pleasure that is at the same instant a quiet injunction to a new way of thinking politics and life? Between February and March of 2014 a whole series of paintings creatively "de-railed" by students of Brock University's creative art program were curated in an exhibition organized by Catherine Parayre and Shawn Serfas at the Niagara Arts Centre. The force of the exhibit, its capacity to charge space with a unique sense of collective mischief and possibility speaks directly to the residual cultural energies of detournement in an era characterized by new(ish) forms of neoliberal everydayness and decay.

The standard cultural destiny of the kind of painting on which a good detournement takes place tends to be the pawn-shop or a tasteless uncle's den: in its ideal setting such an object exists to be ignored or greeted with the most ephemeral of pleasantries. These paintings are rituals hung to stabilize and pleasantly regulate sensation; this is why, remembering Adorno, prettiness was always at the same instant a political philosophy of order (and terror). Detournement takes as its point of departure an object hubristically self-envisioned as an aesthetic conclusion, an object produced for life in autonomy, in the pasture or heaven thought to await every properly aesthetic useless thing. In this sense, it is possible that at root the fantasy of the modern masterpiece was always that of an object finally de-coupled from accidents and matter (this still subtends the whole regulatory infrastructure of the modern art museum which precisely controls the temperature and light of its spaces).

Detournement, of course, originated as a reaction against this bourgeois reduction of art to ornamentation or utility and of the possibilities inherent in aesthetic production to the passive privacies and complicities of property. At its most violent detournement functioned as a shank in the guts of aesthetic idealism: a rupturing of the politically quietist dimensions of mimesis or beauty. "Improving" a painting in the context implied by detournement, then, means simply reontologizing it, cutting away the locks on all its neurotic doors and windows. The paper trash and 
random bits glued to a painting's surface, for example, are subtractions by addition, gestures which re-materialize the object precisely by extending into the surface of the room the threedimensionality repressed by its reduction to framed visual spectacle. The painting is no longer an image, but a densely concentrated crystallization of energy, matter, and form, a labour, not a "work." This is the canonical logic of destructive detournement, a tradition originating theoretically in the troika of Marx, Nietzsche, and Freud which takes as its objective the fragmentary degradation of all things separate, ideal, and high (surrealism, a movement which owes debts to all three of these thinkers and to which situationism is closely related is perhaps the classical iteration of this mode).

There is more, however, at work in these pieces then mere negation or rupture. There is a quiet (even tender) melancholy, here, a nostalgia for the mundane closely linked to the way time is systematically effaced and thereby paradoxically sharpened by an order grounded in universal exchange. It is difficult for objects claimed by the invisibility of bourgeois time, objects always asleep against the backdrop of clocks and sums, not to resonate a certain omnipresence and imminence of death. There is nothing romantic or didactic in this. As modernists like Eliot and Stevens knew well, objects in democratic capitalist peace tend to cathect death in a way far more powerful than romantic gravestones or moors (think of the crack in the tea cup): they are at once effectively eternal, liable to outlive their humans, and utterly exchangeable, things not worth even noticing. Such objects are strange multipliers of our own evanescence (and in some way make dying all the more unbearable and alien). Encoded in the improved work is the history of dereliction and abandonment relayed by the original painting's mundane material fate - its destiny as actual rubbish or half-noticed commodity -, but also the inherited social sense for the latter's generic obsolescence, the patina of tastelessness invoked by precisely the naive realist gesture to beauty or taste. There is something funereal about this generic redundancy and something vaguely redemptive about the return to full (if not transfigured) existence of art objects long thought dead or forgotten.

More interesting, however, is the way this kind of detournement functions as a middle ground established between our modern contempt for the banal and a postmodern nostalgia for a time freed from the Promethean inventiveness (and individualist anxieties) of modernism. In the naive realist painting that the artist lingers near and transforms there is at once contempt and desire, a longing narrated so well by Adorno both for a world in which such naive beauty would no longer be a mask for terror and a time, lost since childhood, in which art was less a message than a comforting massage. These objects, re-drawn on new terms, quietly reprove the modernist injunction to newness, the whole exhausting cycle of creative destruction. Rather than beginning at the abyss of the new, that stare into the infinite traditionally thought to characterize modernism's power, these creations take place humbly on objects discovered by luck or chance. They take comfort in the stable presence of a beginning even as they try to dexterously manage the objectively infinite possibilities schematized by its limits.

There is a strange way, then, in which detournement in this context salvages these paintings, simply by patiently (or libidinously) altering them. This phenomenon is of a piece with that childish desire we still get while standing before a realist mountain or stream to jump right in or to imagine ourselves tinily traversing its impasto valleys. The landscape was always a synthesized dream of freedom, a desire to get lost in a distance that is beautiful, an intuition that the life we are bound to politically by work and obligation is a grotesque bridle on some possible day when walking without destination or pressure might be thinkable again. This need not be that negative Lockean escape famously transmuted by the Romantics into the antinomianism of 
solitude, but can instead channel a social, positive form of liberty, that more capacious freedom afforded by well-governed (and peaceful) republican lands. The landscape still transforms the embodied, postmodern eye into a nostalgic, materialist God: a power alive on an earthly surface so full of alluring wrong turns and joy that the very notion of an afterlife becomes pale and oxymoronic. A good number of the pieces shown at the NAC were less gestures of violent rupture and more acts of idiosyncratic solidarity with these forgotten objects, ways of getting in close to them, "re-beautifying" them. There is a kind of tenderness in this refusal not to condemn these objects for their distance from world-history and from the imperious timelines of aesthetic development and obsolescence. This tender iteration of detournement is new, something invented by the spirit of a generation less taken by negation, a relationship to the past and to its broken promises that is neither restorationist nor kitsch.

At the same time, we should not forget that there is a little bit of 1789 in every properly de-railed painting. A whiff of the barricade, for sure, of creatively transgressed social limit, a return to the carnival of equality: regardless of the difficulty of the expertise implied by a detournement one is immediately solicited by an impression of universality and effortlessness, a productive and ennobling "anybody can do this." This is a humanism without essence, a German Idealist enjoinder to creation de-linked from every notion of telos or harmony. Like the pedagogical works of Kurtag, which encouraged children to begin playing the piano by creatively mashing the keys with their elbows, detournement functions less as an invitation to passively appraise or assess and more like a call to stop procrastinating and produce something yourself. One does not see somebody else's work, something finished, but rather one's own unfinished "business," everything political or beautiful interrupted by the requirements of earning status or income.

Today, the artist who struggles on the edge of structural blight to produce via the old channels of abstraction or figurative excellence inevitably finds their efforts undercut by an encounter with the humiliations of the local. This is a locality paradoxically produced precisely by the end of localities as such, the alive sense of active existential or political presence that would ideally infuse a democratic society minimally in control of its own economic and social reproduction. Such works bear the trace of an artistic ideal so wholly foreign to the basic operations of economic life and so far from the world-historical distributors of aesthetic value that their work cannot but appear as irremediably enfeebled and generic. The absurdity of imagining it possible to locally curate beauty away from a global order meandering into ecological and economic collapse infuses the innocent aesthetic gesture from within with a kind of unwanted decrepitude or failure already described so well by Adorno in Minima Moralia.

Detournement, however, appears to have the power to avoid the pall exercised on locality by a neoliberalism the universality of which perpetually humiliates gestures to an enlivened or idiosyncratic spatial singularity. Rather than demarcating an idealist attempt at the absolute, one thought to emerge out of the separation or purity of creation, detournement begins at its own derivativeness, its proximity to trash and to failed aesthetic experimentation itself. The de-railed painting avoids its consignment to trash - the necessary destiny of all art produced in an age the spirit of which is the opposite of art - precisely by wearing as its badge of honour its familiarity with the garbage heap.

Unlike other forms of painting, detournement has a way of rendering visible the repressed collective potentiality of a space, of rendering clear the way crowds in rooms are always already events-in-the-making, what the Situationists once called a milieu. For some the studied carelessness of the de-railed work will be discredited as little more than an epiphenomenon of the enormous "whatever" of an economy structurally anchored in disposable expansion. Yet, this 
neglects the way these works deploy a general tone and style calculated to tangentially escape precisely the irrealities of technocratic growth. The de-railed space radiates a certain beautiful frugality or resourcefulness, a collective indifference to accumulation, as well as an easy, selfeffacing creativity, wholly at odds with the imperatives of (neo-)liberal productivism. What appears, in other words, is a momentary image from the future, or rather $a$ future, a glimpse of a life re-organized around an alternative set of political desires. The poverty used by detournement, its flagrant meagerness, parallels the material atmospheres of austerity even as it functions as a principled indictment of those not yet capable of glimpsing the political elegance and necessity of the more in less. 